\title{
Örgütsel Stresin Öğretim Elemanlarının Performansı Üzerine Etkisinin İncelenmesine Yönelik Bir Araştırma
}

\author{
A Research into the Effect of Organizational Stress on the Performance of Teaching \\ Staffs
}

Hakan GÖKGÖZ1' ${ }^{1}$ Nevin ALTUĞ²

\begin{abstract}
ÖZET
Çalışma yaşamında örgütlerin başarısının ve veriminin yüksek olması ancak çalışanların performansının artmasıyla mümkün olmaktadır. Çalışanların performanslarııı ilgilendiren unsurlardan birisi de maruz kaldıkları strestir. Stres, kişinin karşılaştığı olumsuz duruma karşı verdiği tepki olarak tanımlanmaktadır. Bireyler hangi meslekte olurlarsa olsunlar, fark etmeseler bile stresle karşılaşmaktadırlar. Çalışanlar açısından stresin neden olduğu olumsuz sonuçlar ise verimsizlik ve iş gücü performansında yaşanan düşüştür. İ̧̧ yaşamındaki değişim ve artan rekabet, örgütleri daha fazla verimli olmaya zorlamakta, bununla beraber örgütlerin çalışanlarından beklentileri artmaktadır. Bu çalışma ile üniversitelerde görevli öğretim elemanlarının karşılaştıkları örgütsel stres faktörleri ile performansları arasındaki ilişkiyi saptamak amacıyla 340 öğretim elemanına anket uygulanmıştır. Araştırmanın sonuçları öğretim elemanlarının karşılaştıkları örgütsel stresin orta düzeylerde olduğunu ve bunun da performanslarına olumlu etkide bulunduğunu göstermektedir.
\end{abstract}

Anahtar Kelimeler: Stres, örgütsel stres, performans

\section{ABSTRACT}

High organizational success and efficiency in working life can only be achieved through increasing employee performance. Stress is one of the factors that influence employee performance. Stress is defined as one's reaction to unfavorable conditions. Irrespective of the specific job they work in, individuals face stress even when they are unaware of it. Speaking for employees, stress manifests itself as inefficiency and decreased performance. Change in working life and increased competitiveness call for increased organizational efficiency, which in turn leads organizations to put higher demands on their employees. This requires organizations to find ways of avoiding stress-causing factors and thus minimize stress. In this study, a questionnaire was done with 340 academic staffs to explore the relation between the performances of academic staff working in service sector and the organizational stress factors they face. The results of the study shows the organizational stress that the academic staffs face is at the average levels and this effects their performances positive.

Keywords: Stress, organizational stress, performance

\section{GíRiş}

Günümüzde çalışanlar gerek günlük yaşamda gerek iş yaşamında farkında bile olmadan stresle karşılaşmaktadır. Gelişen teknoloji ve küreselleşme ile iş hayatında rekabet artmakta, örgütlerin iş yapma şekilleri değişmekte ve çalışanlardan beklentiler yükselmektedir. Artan beklenti düzeyini karşılama çabası içindeki çalışanlar ise iş temposu, zaman baskısı, verimlilik gibi nedenler yüzünden strese maruz kalmaktadır. Bununla birlikte bireyin kendi yapısından kaynaklanan unsurlar, yaşanılan şehir, örgütün bulunduğu çevre, çalışma ortamı, işletme yönetimi gibi nedenler çalışanlarda stres oluşturmaktadır. Stresin çalışanlara etkisi de iş gücü performansının düşüşü ve verimlilik kaybı olarak ortaya çıkmaktadır. Örgütler varlıklarını sürdürmek, büyümek, gelişmek; karlarını ve verimi arttırmak gibi işletme amaçlarına ulaşmak için uğraşmaktadırlar. Bu ise ancak çalışanlarının performansının artmasıyla mümkün olmaktadır. Bu nedenle örgütler, çalışanların karşılaştıkları stres faktörlerini tespit edip stresin neden olduğu olumsuz sonuçları en aza indirebilmek için çaba sarf etmektedirler.

\section{STRES VE ÖRGÜTSEL STRES KAVRAMI}

Modern toplumun hastalığı olarak ifade edilen stres, aslında günlük yaşamın bir parçasıdır. Günümüzde çoğu insan, farkına varmasa bile yoğun bir stres yüküne sahiptir. Günlük rutin yaşamda değişikliğe neden olan herhangi bir gelişme, stres verici olarak değerlendirilmektedir (Özer, 2011: 399). Tarih öncesi devirlerden itibaren var olduğu bilinen stres, günümüzde gerek sosyal yaşamda gerekse iş hayatında yaşanan hızlı değişimle ve yaşamın daha karmaşık hale gelmesiyle birlikte daha da hissedilir hale gel- 
miş ve 21. yüzyılın hastalığı olarak nitelendirilmiştir. Stresin bu denli hissedilir hale gelmesi, stres kaynaklarının sayısının ve çeşitliliğinin artmasının yanı sıra, etkilerinin daha derin ve ağır olmasına bağlanabilmektedir (Lorcu ve Bilgen, 2009: 242). Stres; dayatma, baskı ve belirsizlik yaratan durumların neden olduğu fiziksel ve duygusal tepkiler olarak tanımlanabilmektedir (Daft, 1991: 670). Mevcut kaynakların bireysel beklenti ve motivasyonu karşılamaması durumunda stres oluşmaktadır. Stresin modern tanımları bir dizi temel bileşenleri içermektedir (Blaug, Kenyon ve Lekhi, 2007: 15; Kast ve Rosenzweig, 1985: 654-655):

- Stres kişisel bir deneyimdir,

- Stres bireysel bir tepkidir,

- Strese baskı veya gereksinimler neden olmaktadır,

- Strese gereksinimler ile kaynaklar arasındaki dengesizlik neden olmaktadır,

- Bireyin direnme yeteneğine darbe vurmaktadır,

- Strese bireyler farklı tepkiler verebilmektedirler,

- Stres tamamen kötü değildir, katlanılabilir stres düzeyi performansta iyi etki yapmaktadır,

- Katlanılabiliri aşan fazla stres dengeyi bozabilmektedir.

Genel anlamda örgütsel stres, işin gereklerinin işgörenin kapasitesi, yetenek ve ihtiyaçlarını karşılamaması durumunda ortaya çıkan fiziksel ve duygusal tepkiler olarak tanımlanabilmektedir (Cicei, 2012: 1077; Arrington, 2008: 2; Blaug, Kenyon ve Lekhi, 2007: 4; Park, 2007: 5). Örgütsel stres, işe devamsızlık, yüksek işgören devir hızı, endüstriyel ilişkilerde zorluklar ve düşük kalite kontrolü gibi istenmeyen sonuçlar doğurmaktadır. Ayrıca stresin neden olduğu işgören hastalıkları, verimsizlik, personel devri ve iş kazaları sonucunda ortaya yüksek maliyetler çıkmaktadır (Leontaridi ve Ward, 2002: 1-4).

Stres Kaynakları: Iş hayatının çoğu safhasında birey, örgütten veya dışarıdan kaynaklanan faktörlerin etkisi ile strese girebilmektedir (Aytaç, 1997: 239). Stres yaratan çok sayıda faktör bulunmaktadır. Bireyin iş ve iş dışı çevresi birbirini etkileyerek strese neden olduğu gibi, aynı zamanda işine yönelik duygularını da etkilemektedir. Bir diğer ifade ile stres yaratan faktörler, genel çevre unsurlarından ve çalışma hayatının niteliğinden kaynaklanmaktadır (Aytaç, 2005: 834-835).

Stresin Sonuçları: Örgütsel stresin sonuçları bireysel sonuçlar ve örgütsel sonuçlar olarak iki bölüme ayrılmaktadır (Thong ve Yap, 2000: 683). Stresin Bireysel Sonuçları: İş gereksinimleri ile onları karşılama sürecindeki dengenin olmaması durumunda stres, davranışsal, psikolojik ve fizyolojik sonuçlar doğurmaktadır
(Blaug, Kenyon ve Lekhi, 2007: 15). Stresin Örgütsel Sonuçları: Stresin örgütsel sonuçları, işe devamsızlık, işe yabancılaşma, işgören devir hızı, işte hata yapma, isabetsiz kararlar verme, mesleki hastalıklar, iş kazaları, verimsizlik ve performans düşüklüğü şeklinde sıralanabilmektedir.

\section{PERFORMANS KAVRAMI, ÖRGÜTSEL STRES ILE İLIŞKISi}

Performans, bir insanın bir görevi veya bir işi ne kadar iyi başardığını veya ne kadar kötü yaptığını belirlemeyi kapsayan insan davranışının sonuçlarının bir değerlendirmesidir (George ve Jones, 2012: 158). Buna göre performans, belirlenen koşullara göre bir işin yerine getirilme düzeyi veya işgörenin davranış biçimi olarak tanımlanabilmektedir (Koç ve Topaloğlu, 2012: 299). Bir başka tanıma göre ise bireyin nitelik ve yeteneklerinin işe ilişkin olarak düzenlenmiş olan işletme başarı ölçütleriyle karşılaştırılmasıdır (Gümüştekin ve Öztemiz, 2005: 280). Temel olarak performansta, süreç yönü (davranışsal) ve sonuç yönü olarak ayrım yapılmaktadır. Davranışsal yönü insanların işte yaptıklarını yani eylemin kendisini ifade etmektedir. Performans belirli davranışları kapsamaktadır. Bu kavramsallaştırma yalnızca performans olarak kabul edilerek ölçülebilen eylemleri kastetmektedir (Sonnentag, Volmer ve Spychala, 2008: 427). Ancak her davranış performans kavramı altında toplanamamakta, sadece örgütsel amaçları ilgilendiren davranış performans olarak görülmektedir ve performans "örgütün işe aldığı birinin ne yaptığı ve iyi yaptığı" ile ilgilidir. Böylece performans, eylemin kendisi ile değil, değerlendirme süreçleri ile tanımlanmaktadır. Ayrıca, sadece ölçeklendirilebilen yani ölçülebilen eylemlerin, performansı oluşturduğu kabul edilmektedir. Performansın sonuç yönü bireyin davranışının sonucu veya neticesini ifade etmektedir (Sonnentag, 2002: 5). İşletmeler açısından oldukça önemli olan performans kavramı dikkate alındığında çalışan performansı ile işletme performansının birbirleriyle karşıııklı etkileşim içinde olan kavramlar olduğu görülmekte ve işletme başarısı, çalışanlarının başarılarına bağlıdır (Akgemci ve Güleş, 2010: 114). Çalışanların başarısını engelleyen unsurlardan birisi de örgütte karşılaştıkları strestir.

Stres ve işleyişi arasındaki ilişkiye göre fazla stresin performans üzerinde olumsuz etkileri olsa da her stres kötü değildir. Hans Selye, stresin yaşamın gerekli bir parçası olduğunu ve her zaman organizma için olumsuz sonuçlar içermediğini vurgulamaktadır. Selye'ye göre orta düzeydeki stres bireysel performansı arttırmaktadır (Salami, Ojokuku ve Ilesanmi, 2010: 250; Kavanagh, 2005: 16).

Stres ve performans açısından dört olası varsayım 
bulunmaktadır: (1) stres ve performans arasındaki ilişki ters $U$ şeklinde temsil edebilmektedir, (2) stres performansı arttırabilmektedir, (3) stres performansı düşürebilmektedir ve (4) stresin performans üzerinde hiçbir etkisi yoktur (Tuten ve Neidermeyer, 2004: 27).

Stres ve performans arasındaki ilişkiyi araştıran çok sayıda araştırma sonucunda dört farklı sonuç ortaya çıkabilmektedir. Çünkü bireylerin çalıştıkları ortamlar, çalıştıkları insanlar, iş gerekleri, hedefler, beklentiler, kişisel farklılıklar ve iş ortamında oluşan farklı stres kaynakları her bireyi farklı etkilemekte, bu da onların performansına farklı yansımaktadır (Gümüştekin ve Öztemiz, 2005: 283).

Yapıcı veya olumlu stres birey ve örgüt için olumlu bir rol oynamaktadır. Düşük seviyelerdeki stres, enerjiyi arttırmaktadır. Çalışanı teşvik etmekte, çabayı arttırmakta, yaratıcılığı canlandırmakta, çalışkanlığı ve dikkati arttırmaktadır (Schermerhorn, 1996: 403). Kabul edilebilir optimal stres düzeyi bireye göre değişmektedir. Optimal stres, rekabeti arttırarak sağlıklı ve verimli çalışmayı yaratmaktadır (Leontaridi ve Ward, 2002: 4). Hatta orta düzeydeki stres, bireysel performansı arttırabilmektedir (Kavanagh, 2005: 16). Ancak stres durumu artıp da birey bu durumla başa çıkamayacağını anladığı an ise birey için olumsuz bir durum olan yıkıcı veya olumsuz stres oluşmaktadır (Greiner, 2008: 336). Aşırı stres altında bireylerin devamsızık, hata yapma ve kaza oranı yüksek, iş tatmini azdır, yalnızca performansları olumsuz etkilenmekle kalmamakta; aynı zamanda stresin neden olduğu tüm olumsuz sonuçlar yaşanmaktadır (Gümüştekin ve Öztemiz, 2005: 283). Denetlenebilen ve stres toleransını aşmayan yönetilebilir bir stres, bireyde var olan potansiyelin açığa çıkmasında katalizör etkisi yapmakta ve performansını yükseltmektedir (Aksoy ve Kutluca, 2004: 463).

\section{ARAŞTIRMANIN AMACI}

Bu araştırma ile örgütsel strese neden faktörler, öğretim elemanlarının örgütsel stres düzeyleri ile bunun iş performanslarına etkisinin tespit edilmesi amaçlanmıştır. Örgütsel stres faktörlerinin performans üzerindeki etkilerini ölçmeye yönelik çalışmalar daha önce de yapılmıştır. Balcı 1993 yılında yaptığı çalışmasında Ankara'daki üniversitelerde görevli 86 öğretim elemanının stres faktörlerini, stresle baş etme stratejilerini ve stres durumundaki iş performanslarını incelemiştir. Stres faktörlerini; iş yükü, çatışma ve uyumsuzluk, mesleki ilkeler, işleyiş ve ilişki şeklinde dört grupta ve performans algısını işten kaçınma, işbirliği eksikliği, işi aksatma ve kendini kontrol olarak dört grupta incelemiş, katılımcıların yaş ve cinsiyete bağlı olarak işten kaçınma tepkisi gösterdiklerini tespit etmiştir.
Aytaç ve diğerlerinin 2001 yllında Türkiye'deki devlet üniversitelerinden 3512 öğretim elemanı ile yaptıkları araştırmada öğretim elemanlarının \% 21'inin bilimsel çalışma için yeterli zamana sahip olmadığı, \% 18'inin olduğu ve \% 61'inin belli dönemlerde olduğu; kadın akademisyenlerin çoğunluğunun yeterli zamana sahip olmadığı ancak akademik unvan arttıkça zaman bulma oranının arttığı belirtilmiştir. Akademisyenleri etkileyen faktörlerin başında "öğretim elemanları arasında yaşanan sorunlar" ve "kurumun fiziki koşulları" geldiği ve erkek akademisyenlerin daha fazla etkilendiği bulunmuştur. Unvan yükseldikçe girilen ders saatinin azaldığını; ders ücreti yaratması için ikinci öğretim uygulamasını \% 64'ünün onaylamadığını saptamışlardır. Daha yüksek düzeyde maddi tatmin sağlayacak başka bir iş fırsatı karşılarına çıktığında akademisyenlerin yarıya yakınının akademik kariyerlerini terk etme düşüncesinde oldukları ve araştırma görevlilerinin çoğunlukta olduğunu tespit etmişlerdir.

Okutan ve Tengilimoğlu 2002 yılındaki çalışmalarında Ankara Devlet Demiryollarındaki 300 çalışanın iş stresi faktörlerini, stresin tepki ve belirtilerini, stresin performanslarına etkisini saptamaya çalışmışlardır. İş stresi faktörlerini; iş ve iş ortamından, örgütsel rolden, kariyer gelişiminden, işteki beşeri ilişkilerden, örgütsel yapı ve iklimden, örgüt dışından kaynaklanan stres faktörleri olarak altı bölümde ele almış ve işte hata yapma, işe gitme isteksizlik, işin niteliğinin düşmesi ve izin veya rapor alarak işten uzaklaşma şeklinde stresin performansa olumsuz etkisi olduğunu ifade etmişlerdir.

Yılmaz ve Ekici 2003 yılında Karayolları 16. Bölge Müdürlüğünde çalışan 156 personel ile yürüttükleri araştırmada çalışanların eğitim düzeyleri azaldıkça stres anlarında birlikte çalıştıkları kişilerle işbirliği kuramama sorununu daha fazla yaşadıkları ve yine stres anlarında daha fazla isabetsiz kararlar verdiklerini tespit etmişlerdir.

Aksoy ve Kutluca 2004 yilında Malatya'da 284 askeri personel ile yaptıkları araştırmada örgütsel stresin performansı etkileyen davranışları incelenmiş ve örgütteki stres sonucu çalışanlarda; iş yapma ve çalışma isteğinin kaybolması, işe gitmede isteksizlik, kendi kabuğuna çekilme, işlemlerde hata yapma, aşırı alıngan olma, işten ayrılmayı düşünme, yapılan işin kalitesini düşürme, çalışma arkadaşlarına karşı kırıcı olma şeklinde olumsuz davranışların ortalama değerlerinin yüksek olduğunu belirtmişlerdir.

Lorcu ve Bilgen 2009 yılında Trakya bölgesinde 388 sağlık ve eğitim çalışanı ile yaptığı araştırmada strese neden olan unsurları, stresin yarattığı sonuçları 
ve stresin performans üzerindeki etkisini incelemişler; katılımcıların \% 78,3'ünün performanslarının stresten etkilendiğini ve \% 95'inde stresin performanslarını olumsuz yönde etkilediğini bulmuşlardır.

Kara ve Koç, 2009 yılında Gazi Üniversitesi'nde görevli 350 öğretim elemanı ile yaptıkları çalışmada stresle başa çıkma davranışlarından Kabul-Bilişsel Yeniden Yapılanma (stres yaratan problemi unutmak için kitap okuma, müzik dinleme, sinemaya gitme, televizyon seyretme veya değişik işlerle ilgilenme) davranışlarına kadın öğretim elemanlarının daha fazla eğilim gösterdiğini belirtmiştirler.

Aydın, Üçüncü ve Taşdemir'in 2011 yılında Karadeniz Teknik Üniversitesinde çalışan 180 öğretim üyesi ile yaptıkları çalışmada ise öğretim üyeleri üzerinde stres yaratan en önemli faktörlerin bireysel ve örgütsel faktörler olduğunu bulmuşlardır.

\section{ARAŞTIRMANIN YÖNTEMI}

Araştırmanın örneklemini Trakya bölgesinde bulunan iki devlet üniversitesinde görev yapmakta olan öğretim elemanları oluşturmaktadır. Araştırmada veriler "anket tekniği" ile toplanmıştır. Anket formunun oluşturulmasında benzer amaçla yapılan çalışmalardan yararlanılmıştır. Anket formundaki performans algısı ölçeği Okutan ve Tengilimoğlu'nun 2002 yıldaki makale çalışmalarından, stres değerleme ölçeği Aydın'ın 2004 yılındaki doktora tez çalışması ve Ergun'un 2008 yılındaki yüksek lisans tez çalışmasından alınmıştır. Üç bölümde oluşan anketin birinci bölümünde katılımcıların demografik özelliklerini belirlemeye yönelik 7 soru yer almaktadır. Anketin ikinci bölümünde öğretim elemanlarının örgütsel stres faktörlerini belirlemeye yönelik 42 sorudan oluşan stres değerleme ölçeği bulunmaktadır. Bu sorular 5 'li likert ölçeğinde olup 1 "çok fazla", 2 "çok", 3 "orta", 4 "az", 5 "hiç" ifadeleriyle yanıtlanmak üzere hazırlanmıştır. 42 sorunun hepsi olumsuz anlamlı olduğundan 1 "çok fazla" seçeneği en olumsuz ve istenmeyen durumu ifade ederken 5 "hiç" seçeneği en olumlu durumu göstermektedir. Bu nedenle elde edilen sonuçlar üzerinden değerlendirme yapılırken 5'e yaklaştıkça stresin azaldığını, 1'e yaklaştıkça ise stresin arttığını gösteren yorumlar yapılacaktır. Anketin üçüncü bölümünde ise performans algısına yönelik 9 soru yer almaktadır. Bu sorular da yine $5^{\prime}$ li likert ölçeğinde olup 1 "çok fazla", 2 "çok", 3 "orta", 4 "az", 5 "hiç" ifadeleriyle yanıtlanmak üzere hazırlanmıştır. 9 sorunun hepsi olumsuz anlamlı olduğu için 1 "çok fazla" seçeneği en olumsuz ve istenmeyen durumu ifade ederken 5 "hiç" seçeneği en olumlu durumu göstermektedir. Bu yüzden elde edilen sonuçlar üzerinden değerlendirme yapılırken 5'e yaklaştıkça iş gücü performansında artış olduğu- nu, 1'e yaklaştıkça ise iş gücü performansında düşüş olduğunu gösteren yorumlar yapılacaktır.

Verilerin değerlendirilmesinde tanımlayıcı istatistiksel metotlar (Frekans, Yüzde, Ortalama, Standart sapma) ve hipotez testleri (Bağımsız İki Örnek t - Testi, Tek-Yönlü Varyans Analizi, Korelasyon Analizi ve Regresyon Analizi) kullanılmıştır.

\subsection{Araştırmanın Hipotezleri}

Araştırmanın hipotezleri şu şekilde sıralanmaktadır:

Hipotez 1: Bireyden kaynaklanan stres faktörleri demografik özelliklere göre farklılık göstermektedir.

Hipotez 2: İş yapısından kaynaklanan stres faktörleri demografik özelliklere göre farklılık göstermektedir.

Hipotez 3: Örgütsel yapı ve politikalardan kaynaklanan stres faktörleri demografik özelliklere göre farklılık göstermektedir.

Hipotez 4: Örgüt içi fiziksel koşullardan kaynaklanan stres faktörleri demografik özelliklere göre farklılık göstermektedir.

Hipotez 5: Genel çevresel unsurlardan kaynaklanan stres faktörleri demografik özelliklere göre farklılık göstermektedir.

Hipotez 6: İş başarısı değerlendirmesine ilişkin performans boyutu demografik özelliklere göre farklılık göstermektedir.

Hipotez 7: İ̧ doyumu değerlendirmesine ilişkin performans boyutu demografik özelliklere göre farklılık göstermektedir.

Hipotez 8: Stres faktörleri ile iş gücü performansı arasında ilişki bulunmaktadır.

\subsection{Demografik Özelliklere Ait Sonuçlar}

Ankete katılan 340 öğretim elamanının \% 53,2'sini 25-35 yaş arası, \% 27,1'ini 36-45 yaş arası, \% 11,8'ini 46-55 yaş arası, \% 5,3'ünü 25 yaş altı ve \% 2,6'sını 56 yaş ve üzeri öğretim elemanları oluşturmaktadır.

Ankete katılanların \% 47,9'u kadın ve \% 52,1'i erkek öğretim elemanıdır. Öğretim elemanlarının \% $55,3^{\prime}$ ü evli ve \% 44,7'si ise bekardır. Eğitim durumlarında \% 18,8'i lisans mezunu, \% 51,5'i yüksek lisans mezunu ve \% 29,7'si doktora mezunudur.

Katılımcıların \% 49,7'sini öğretim görevlileri, \% 20,6'sını yardımcı doçentler, \% 15'ini araştırma görevlileri, \% 8,5'ini okutmanlar, \% 4,7'sini doçentler, $\% 0,9^{\prime}$ 'unu profesörler ve \% 0,6'sını uzmanlar oluşturmaktadır.

Meslekteki çalışma sürelerinde \% 53,8'i 1-10 yıl arası, \% 24,1'i 11-20 yıl arası, \% 15'i 1 yıldan az ve \% 7,1 'i 21 yıl ve üzeri çalışan öğretim elemanlarından oluşmaktadır. 
Halen bulundukları kurumda çalışma süresinde ise öğretim elemanlarının \% 49,7'sini 1-5 yıl arası, \% 18,8'ini 1 yıldan az, \% 9,7'sini 6-10 yıl arası ve \% 21,8'ini 11 yıl ve üzeri süredir çalışanlar oluşturmaktadır.

\section{3. Ölçeğin Güvenilirliği}

Anket formunun genel güvenilirliği 0,95, stres değerleme ölçeği değişkenlerinin genel güvenilirliği 0,94 ve performans algısı ölçeği değişkenlerinin genel güvenilirliği ise 0,87 olarak bulunmuştur. Faktör analizinden sonra her boyut için ayrı ayrı güvenilirlik analizi yapılmıştır. Güvenilirlik analizine göre stres değerleme değişkenlerini oluşturan her bir faktör için elde edilen Cronbach's Alpha değerleri sırasıyla Bireyden kaynaklanan stres değişkenleri için 0,680 , İ̧̧ yapısından kaynaklanan stres değişkenleri için 0,797, Örgütsel yapı ve politikalardan kaynaklanan stres değişkenleri için 0,950, Örgüt içi fiziksel koşullardan kaynaklanan stres değişkenleri için 0,744 ve Genel çevresel unsurlardan kaynaklanan stres değişkenleri için 0,784 şeklinde ölçülmüştür. Performans algısı ölçeğine ait iş başarısı boyutunun güvenilirliği 0,779 ve iş doyumu boyutunun güvenilirliği ise 0,803 olarak bulunmuştur.

\subsection{Araştırmanın Değişkenleri}

Çalışmada kullanılan performans algısına ait değişkenler bağımlı değişkenler ve strese ait değişkenler ise bağımsız değiş̧kenler olarak değerlendirilmiştir. Stres değerleme ölçeğine yapılan faktör analizi sonucunda, 42 sorunun 5 faktör altında toplandığı (Tablo 1) ve bu faktörlerin toplam varyansın $\% 61,673$ 'ünü açıkladığı belirlenmiştir. Performans algısı ölçeğinin faktör analizi sonucunda ise 9 sorunun 2 faktör altında toplandığı (Tablo 2) ve bu faktörlerin toplam varyansın \% 60,855'ini açıkladığı belirlenmiştir.

Tablo 1: Stres Değerleme Değişkenlerinin Tanımsal İstatistik Analizleri

\begin{tabular}{|c|c|c|c|}
\hline & STRES DEĞERLEME DEĞiŞKENLERI & Ortalama & $\begin{array}{c}\text { Standart } \\
\text { Sapma }\end{array}$ \\
\hline BiRE & YDEN KAYNAKLANAN STRES FAKTÖRLERI & 3,46 & 0,82 \\
\hline 1 & İşin sağlık durumunu (psikolojik ve bedensel) olumsuz etkilemesi & 3,40 & 1,17 \\
\hline 2 & Aile ve sosyal yaşama yeterli zaman ayıramama & 3,02 & 1,08 \\
\hline 23 & Öğretim elemanları arasındaki yükselme hırsı ve rekabete bağlı olarak ortaya çıkan sorunlar & 3,43 & 1,24 \\
\hline 30 & İş arkadaşları ile uyumsuzluk ve çatışma yaşanması & 3,99 & 1,13 \\
\hline iş Y & IPISINDAN KAYNAKLANAN STRES FAKTÖRLERI & 3,62 & 0,76 \\
\hline 3 & İş yoğunluğu (aşırı ders yükü) & 2,94 & 1,11 \\
\hline 4 & İşin monotonluğu & 3,55 & 1,03 \\
\hline 5 & Mesleki riskler ve meslek hastalıkları & 3,78 & 1,08 \\
\hline 6 & İşi belli sürede bitirme zorunluluğu (ders saatleri) & 3,05 & 1,12 \\
\hline 7 & Yeterli araç ve gereçten yoksun olma & 3,14 & 1,21 \\
\hline 8 & Görevde hata yapma olasılığı & 3,87 & 0,93 \\
\hline 9 & Önemli kararlar verme zorunluluğu & 3,44 & 1,09 \\
\hline 10 & İşin sürekli göz önünde yapılması zorunluluğu & 3,31 & 1,20 \\
\hline 11 & Öğrenci memnuniyetsizliği veya şikayet edilme korkusu & 4,12 & 0,94 \\
\hline 12 & Görev yeri ile ilgili sık değişiklikler yapılması & 4,33 & 1,01 \\
\hline 13 & Çalışma saatlerinde belirsizlik veya uygunsuzluk & 4,19 & 0,99 \\
\hline ÖRC & ÜTSEL YAPI VE POLITIKALARDAN KAYNAKLANAN STRES FAKTÖRLERI & 3,55 & 0,87 \\
\hline 14 & Örgütsel amaç ve politikalara yeteri kadar uyulmadığı duygusu & 3,77 & 1,10 \\
\hline 15 & Rolle ilgili sorumluluklar ve bunların yoğunluğu & 3,37 & 1,14 \\
\hline 16 & Görev dağılımındaki adaletsizlik & 3,42 & 1,29 \\
\hline 17 & Kendi ürettiği işin dışında bilgi verilmeme, dışlanma & 3,77 & 1,20 \\
\hline 18 & Yetersiz maaş ve ücret dengesizliği & 2,97 & 1,34 \\
\hline 19 & Mesleki yönden kendini geliştirme olanaklarının sağlanamaması & 3,22 & 1,23 \\
\hline 20 & Yapılan işin başkalarınca önemsenmemesi & 3,47 & 1,22 \\
\hline
\end{tabular}




\begin{tabular}{|c|c|c|c|}
\hline 21 & Amirlerle olan ilişkilerde ortaya çıkan sürtüşme ve sorunlar & 3,75 & 1,27 \\
\hline 22 & Öğretim elemanlarının bir üst tarafından takdir edilmemesi & 3,54 & 1,30 \\
\hline 24 & Yönetimden farklı görüşlerde olma & 3,64 & 1,13 \\
\hline 25 & Karar aşamasında üst yönetimden destek alamama & 3,68 & 1,19 \\
\hline 26 & Kararlara katılamama & 3,56 & 1,19 \\
\hline 27 & Sıkı denetim ve gözetim & 3,79 & 1,05 \\
\hline 28 & Görevini yaparken engellendiği duygusuna kapılma & 3,90 & 1,15 \\
\hline 29 & Yönetsel uygulamaları eleştirememe & 3,49 & 1,26 \\
\hline 31 & Performans değerlendirmede adaletsizlik & 3,54 & 1,28 \\
\hline 32 & İş yerinde dedikodunun yaygın olması & 3,21 & 1,35 \\
\hline 33 & Aynı anda birden fazla amire karşı sorumlu olma & 3,81 & 1,22 \\
\hline 34 & Gizli ayrımcılık ve adam kayırma & 3,36 & 1,38 \\
\hline 35 & Otorite eksikliği & 3,68 & 1,26 \\
\hline 36 & Yeni durumlara uyabilme durumu & 3,66 & 1,14 \\
\hline \multicolumn{2}{|r|}{ ÖRGÜT IÇi FiZiKSEL KOŞULLARDAN KAYNAKLANAN STRES FAKTÖRLERI } & 3,35 & 1,05 \\
\hline 37 & Sınıfların kalabalık ve gürültülü olması & 3,16 & 1,30 \\
\hline 38 & Sınıflarda ısı ve aydınlatmanın kötü olması & 3,44 & 1,31 \\
\hline 39 & Okulda dinlenme olanağının bulunmayışı & 3,46 & 1,25 \\
\hline \multicolumn{2}{|r|}{ Genel Çevresel Unsurlardan Kaynaklanan Stres Faktörleri } & 3,87 & 0,95 \\
\hline 40 & Siyasal karışma ve baskı & 4,26 & 1,08 \\
\hline 41 & Ülkenin ekonomik ve siyasal durumu & 3,49 & 1,25 \\
\hline 42 & Medyadan dinlenilen ve takip edilen haberlerin iş hayatına etkileri & 3,87 & 1,08 \\
\hline
\end{tabular}

Stres düzeylerini belirlemek amacıyla kullanılan ölçekten elde edilen puanlar incelendiğinde çalışanlarda en çok stres yaratan kriterlerin başında 2,94 ortalama değer ile iş yoğunluğu gelmektedir. Diğer bir stres kaynağı ise 2,97 ortalama değer ile yetersiz maaş ve ücret dengesizliğidir. Aileye ve sosyal yaşama vakit ayıramama (3,02 ortalama) ve işi belli sürede bitirme zorunluluğu (3,05 ortalama) diğer yüksek stres faktörleri olarak sıralanabilmektedir.

Tablo 2: Performans Algısı Değişkenlerinin Tanımsal İstatistik Analizleri

\begin{tabular}{|c|l|c|c|}
\hline \multicolumn{2}{|c|}{ PERFORMANS ALGISI DEĞişKENLERI } & Ortalama & $\begin{array}{c}\text { Standart } \\
\text { Sapma }\end{array}$ \\
\hline \multicolumn{2}{|c|}{ İs Başarısını Azaltan Faktörler } & 4,19 & 0,70 \\
\hline 1 & İşte hata yapma & 4,07 & 0,87 \\
\hline 4 & İşte kendini yetersiz hissetme & 4,43 & 0,84 \\
\hline 5 & Yapılan işin niteliğinin düşmesi & 3,85 & 1,11 \\
\hline 7 & İsabetsiz kararlar verme & 4,41 & 0,76 \\
\hline İş Doyumunu Azaltan Faktörler & 4,33 & 0,70 \\
\hline 2 & İşe gitmede isteksizlik & 4,11 & 0,97 \\
\hline 3 & İşten ayrılma düşünceleri & 4,31 & 0,96 \\
\hline 6 & İzin ve rapor alarak işten uzaklaşma isteği & 4,49 & 0,91 \\
\hline 8 & İş çevresine karşı kırıcı davranma & 4,44 & 0,82 \\
\hline 9 & Birlikte çalışılan kişilerle işbirliği kuramama & 4,30 & 0,97 \\
\hline
\end{tabular}


Performans algısı değişkenleri, İş başarısını azaltan ve İş doyumunu azaltan faktörler olmak üzere iki boyutta ele alınmıştır. İş başarısını azaltan faktörlerin ortalaması 4,19 ve iş doyumunu azaltan faktörlerin ortalaması 4,33 olarak bulunmuştur. Ortalamanın 5'e yakın olması çalışanların örgütsel strese bağlı olarak işgücü performanslarında hissettikleri yetersizliğin çok düşük seviyelerde olduğu ve bu da çalışanların iş başarııının ve iş doyumunun yüksek olduğu anlamına gelmektedir.

\subsection{Araştırma Hipotezlerinin Test Edilmesi}

\subsubsection{Bireyden Kaynaklanan Stres Faktörlerinin Demografik Özelliklere Göre Farklılığı}

$\mathrm{H}_{1}$ : Bireyden kaynaklanan stres faktörleri demografik özelliklere göre farklılık göstermektedir.

Tablo 3: Bireyden Kaynaklanan Stres Faktörlerinin Çalışanların Demografik Özelliklerine Göre Farklılığının Test Sonuçları

\begin{tabular}{|c|c|c|c|c|}
\hline \multicolumn{2}{|c|}{ Demografik Özellikler } & Ortalama & $\begin{array}{c}\text { t/F } \\
\text { Deăeri }\end{array}$ & p değeri \\
\hline \multirow{4}{*}{$\begin{array}{l}\text { Mesleki } \\
\text { Tecrübe }\end{array}$} & 1 Yıldan Az & 3,81 & \multirow{4}{*}{3,832} & \multirow{4}{*}{$0,010^{*}$} \\
\hline & 1-10 Yıl & 3,39 & & \\
\hline & 11-20 Yll & 3,41 & & \\
\hline & 21 Yıl ve üzeri & 3,35 & & \\
\hline \multirow{4}{*}{$\begin{array}{c}\text { Kurumda } \\
\text { Çalışılan Süre }\end{array}$} & 1 Yıldan Az & 3,81 & \multirow{4}{*}{5,597} & \multirow{4}{*}{$0,001 * *$} \\
\hline & 1-5 Yıl & 3,35 & & \\
\hline & 6-10 Yıl & 3,55 & & \\
\hline & 11 Yıl ve üzeri & 3,37 & & \\
\hline
\end{tabular}

( Not: * \% 95 güven aralığında anlamlı, ** \% 99 güven aralığında anlamlı olduğunu göstermektedir)

Bireyden kaynaklanan stres faktörlerinden etkilenme düzeylerinde mesleki tecrübe süresi açısından 21 yıl ve üzeri süredir çalışanların 3,35 ortalama değer ile stres düzeyleri yüksektir. Kurumda çalışılan süre açısından ise 3,35 ortalama değer ile 1-5 yıl arası çalışanlar bireyden kaynaklanan stres faktörlerinden daha fazla etkilenmektedir.

5.5.2. İs Yapısından Kaynaklanan Stres Faktörlerinin Demografik Özelliklere Göre Farklılığı

$\mathrm{H}_{1}$ : İş yapısından kaynaklanan stres faktörleri demografik özelliklere göre farklılık göstermektedir.
Tablo 4: İş Yapısından Kaynaklanan Stres Faktörlerinin Çalışanların Demografik Özelliklerine Göre Farklılığının Test Sonuçları

\begin{tabular}{|c|c|c|c|c|}
\hline \multicolumn{2}{|c|}{ Demografik Özellikler } & \multirow{2}{*}{\begin{tabular}{|c|} 
Ortalama \\
3,68 \\
\end{tabular}} & \multirow{2}{*}{$\begin{array}{c}\text { t/F } \\
\text { Değeri }\end{array}$} & \multirow{2}{*}{$\begin{array}{l}\text { İşaret } \\
\text { Değeri } \\
\text { (p) }\end{array}$} \\
\hline \multirow{7}{*}{ Unvan } & Araştırma Görevlisi & & & \\
\hline & Uzman & 3,09 & \multirow{6}{*}{2,297} & \multirow{6}{*}{$0,035^{*}$} \\
\hline & Okutman & 3,29 & & \\
\hline & Öğretim Görevlisi & 3,64 & & \\
\hline & $\begin{array}{l}\text { Yardımcı Doçent } \\
\text { Doktor }\end{array}$ & 3,62 & & \\
\hline & Doçent Doktor & 3,59 & & \\
\hline & Profesör Doktor & 4,21 & & \\
\hline \multirow{4}{*}{$\begin{array}{l}\text { Mesleki } \\
\text { Tecrübe }\end{array}$} & 1 Yıldan Az & 3,84 & \multirow{4}{*}{3,789} & \multirow{4}{*}{$0,011 *$} \\
\hline & $1-10 Y_{\prime l}$ & 3,53 & & \\
\hline & 11-20 YII & 3,63 & & \\
\hline & 21 Yıl ve üzeri & 3,70 & & \\
\hline \multirow{4}{*}{$\begin{array}{c}\text { Kurumda } \\
\text { Çalışıllan Süre }\end{array}$} & 1 Yıldan Az & 3,79 & \multirow{4}{*}{3,292} & \multirow{4}{*}{$0,021^{*}$} \\
\hline & $1-5$ Yıl & 3,52 & & \\
\hline & 6-10YII & 3,70 & & \\
\hline & 11 Yıl ve üzeri & 3,63 & & \\
\hline
\end{tabular}

( Not: * \% 95 güven aralığında anlamlı olduğunu göstermektedir.)

İs yapısından kaynaklanan stres faktörlerinden etkilenme düzeyleri unvan açısından, 3,09 ortalama değer ile uzmanlarda daha yüksek olduğu görülmektedir. Mesleki tecrübe süresinde iş yapısından kaynaklanan stresten 3,53 ortalama değer ile 1-10 yıl arası çalışanlar daha fazla etkilenmektedir. Kurumda çalışılan süre açısından ise 3,52 ortalama değer ile 1-5 yıl arası çalışanlar iş yapısından kaynaklanan stresten daha fazla etkilenmektedirler.

5.5.3.Örgütsel Yapı ve Politikalardan Kaynaklanan Stres Faktörlerinin Demografik Özelliklere Göre Farklılığı

$\mathrm{H}_{1}$ : Örgütsel yapı ve politikalardan kaynaklanan stres faktörleri demografik özelliklere göre farklılık göstermektedir. 
Tablo 5: Örgütsel Yapı ve Politikalardan Kaynaklanan Stres Faktörlerinin Çalışanların Demografik Özelliklerine Göre Farklıı̆̆ının Test Sonuçları

\begin{tabular}{|c|c|c|c|c|}
\hline \multicolumn{2}{|c|}{ Demografik Özellikler } & Ortalama & $\begin{array}{c}\text { t/F } \\
\text { Deăeri }\end{array}$ & $\begin{array}{l}\text { Işaret } \\
\text { Değeri }\end{array}$ \\
\hline \multirow{4}{*}{$\begin{array}{l}\text { Mesleki } \\
\text { Tecrübe }\end{array}$} & 1 Yıldan Az & 3,96 & \multirow{4}{*}{4,600} & \multirow{4}{*}{$0,004^{* *}$} \\
\hline & 1-10 Yוl & 3,49 & & \\
\hline & 11-20 Yll & 3,48 & & \\
\hline & 21 Yıl ve üzeri & 3,41 & & \\
\hline \multirow{4}{*}{$\begin{array}{c}\text { Kurumda } \\
\text { Çalışılan Süre }\end{array}$} & 1 Yıldan Az & 3,95 & \multirow{4}{*}{5,962} & \multirow{4}{*}{$0,001^{* *}$} \\
\hline & 1-5 Yıl & 3,44 & & \\
\hline & 6-10 YIl & 3,57 & & \\
\hline & 11 Yıl ve üzeri & 3,45 & & \\
\hline
\end{tabular}

( Not: * \% 99 güven aralığında anlamlı olduğunu göstermektedir.)

Örgütsel yapı ve politikalardan kaynaklanan stres faktörlerinden etkilenme düzeyleri, mesleki tecrübe bakımından 21 yıl ve üzeri çalışanlarda 3,41 ortalama değer ile diğer çalışanlara göre daha yüksektir. Kurumda çalışılan süre boyutunda 3,44 ortalama değer ile 1-5 yıl arası çalışanların ve 3,45 ortalama değer ile de 11 yıl ve üzeri çalışanların örgütsel yapı ve politikaları daha fazla stres etkeni olarak gördüğü görülmektedir.

5.5.4.Örgüt İçi Fiziksel Koşullardan Kaynaklanan Stres Faktörlerinin Demografik Özelliklere Göre Farklılığı

$\mathrm{H}_{1}$ : Örgüt içi fiziksel koşullardan kaynaklanan stres faktörleri demografik özelliklere göre farklılık göstermektedir.

Öğretim elemanlarının demografik özelliklerine göre örgüt içi fiziksel koşulların neden olduğu stres kaynaklarının farklılık gösterip göstermediğini ortaya çıkarmak için yapılan bağımsız örneklem $t$ testi sonucunda bir farklılık saptanamamıştır.

5.5.5.Genel Çevresel Unsurlardan Kaynaklanan Stres Faktörlerinin Demografik Özelliklere Göre Farklılığı

$\mathrm{H}_{1}$ : Genel çevresel unsurlardan kaynaklanan stres faktörleri demografik özelliklere göre farklılık göstermektedir.

Kurumun genel çevresel unsurlarının yarattığı stres kaynaklarının öğretim elemanlarının demografik özelliklerine göre farklılık gösterip göstermediğini belirlemek amacıyla yapılan bağımsız örneklem $t$ testi sonucunda anlamlı bir farklıılık bulunamamıştır.

5.5.6.İ̧ Başarısı Değerlendirmesine iliş̧kin Performans Boyutunun Demografik Özelliklere Göre Farklılığı

$\mathrm{H}_{1}$ : İş başarısı değerlendirmesine ilişkin performans boyutu demografik özelliklere göre farklılık göstermektedir.
Tablo 6: İş Başarısı Değerlendirmesine İlişkin Performans Boyutunun Demografik Özelliklere Göre Hipotez Testi Sonuçları

\begin{tabular}{|c|c|c|c|c|}
\hline \multicolumn{2}{|c|}{ Demografik Özellikler } & Ortalama & t/F Değeri & $\begin{array}{c}\text { Işaret Değeri } \\
(p)\end{array}$ \\
\hline \multirow{2}{*}{ Cinsiyet } & Kadın & 4,30 & \multirow{2}{*}{2,745} & 0 \\
\cline { 2 - 3 } & Erkek & 4,00 & & \\
\hline
\end{tabular}

( Not: ** \% 99 güven aralığında anlamlı olduğunu göstermektedir.)

Performans algısı ölçeğinde iş başarısının demografik özelliklere göre farklılıklarında 4,30 ortalama değer ile kadınların iş başarısı performanslarının erkeklere göre daha yüksek olduğu bulunmuştur.

5.5.7.ìş Doyumu Değerlendirmesine ilişskin Performans Boyutunun Demografik Özelliklere Göre Farklılığı

$\mathrm{H}_{1}$ : İş doyumu değerlendirmesine ilişkin performans boyutu demografik özelliklere göre farklılık göstermektedir.

Tablo 7: İş Doyumu Değerlendirmesine İlişkin Performans Boyutunun Demografik Özelliklere Göre Hipotez Testi Sonuçları

\begin{tabular}{|c|c|c|c|c|}
\hline \multicolumn{2}{|c|}{ Demografik Özellikler } & Ortalama & $\begin{array}{c}\text { t/F } \\
\text { Değeri }\end{array}$ & $\begin{array}{c}\text { Isşaret } \\
\text { Değeri }(p)\end{array}$ \\
\hline \multirow{4}{*}{ Yaş } & 25 altı & 4,06 & & \\
\cline { 2 - 3 } & $25-35$ & 4,33 & & \\
\cline { 2 - 3 } & $36-45$ & 4,43 & \multirow{2}{*}{2,532} & \multirow{2}{*}{$0,040^{*}$} \\
\cline { 2 - 3 } & $46-55$ & 4,14 & & \\
\cline { 2 - 3 } & 56 ve üstü & 4,69 & & \\
\hline
\end{tabular}

( Not: * \% 95 güven aralığında anlamlı olduğunu göstermektedir.)

Çalışanlarda performansın iş doyumu boyutunun demografik özelliklere göre farklılıklarında 4,69 ortalama değer ile 56 yaş ve üzeri çalışanların iş doyumlarının daha yüksek olduğu saptanmıştır. 25 yaşın altındaki çalışanlar ise iş doyumu en az olan grup olarak görülmektedir.

\subsubsection{Stres Faktörleri İle İş Gücü Performansı Arasındaki İlişki}

$H_{1}$ : Stres faktörleri ile iş gücü performansı arasında ilişki bulunmaktadır.

Stres boyutları (bağımsız değişkenler), Bireyden kaynaklanan stres faktörleri, İş yapısından kaynaklanan stres faktörleri, Örgütsel yapı ve politikalardan kaynaklanan stres faktörleri, Örgüt içi fiziksel koşullardan kaynaklanan stres faktörleri, Genel çevresel unsurlardan kaynaklanan stres faktörleri ve performans algısı boyutları (bağımlı değişkenler) ise İş başarısı ve İ̧ doyumu şeklinde oluşmaktadır. Çalışanların performanslarının örgütsel stres faktörlerinden etkilenme 
düzeyleri iş başarısı ve iş doyumunun değerlendirilmesi şeklinde iki boyutta ele alınmıştır. Her bir performans boyutunun stres faktörlerinden etkilenmesi doğrusal regresyon modelleri ile gösterilmiştir. Regresyon modeli oluşturulmadan önce tüm boyutların kendi aralarındaki karşılıklı ilişkisini gösteren korelasyon analizi yapılmıştır.

Tablo 8: Performans Algısı Boyutları ve Stres Faktörleri Arasındaki Korelasyon Analizi

\begin{tabular}{|l|c|c|}
\hline & İş Başarısı & $\begin{array}{c}\text { İş } \\
\text { Doyumu }\end{array}$ \\
\hline Bireyden kaynaklanan stres faktörleri & $0,524^{* *}$ & $0,609^{* *}$ \\
\hline $\begin{array}{l}\text { İş yapısından kaynaklanan stres } \\
\text { faktörleri }\end{array}$ & $0,506^{* *}$ & $0,475^{* *}$ \\
\hline $\begin{array}{l}\text { Örgütsel yapı ve politikalardan } \\
\text { kaynaklanan stres faktörleri }\end{array}$ & $0,494^{* *}$ & $0,594^{* *}$ \\
\hline $\begin{array}{l}\text { Örgüt içi fiziksel koşullardan } \\
\text { kaynaklanan stres faktörleri }\end{array}$ & $0,329^{* *}$ & $0,372^{* *}$ \\
\hline $\begin{array}{l}\text { Genel çevresel unsurlardan } \\
\text { kaynaklanan stres faktörleri }\end{array}$ & $0,427^{* *}$ & $0,472^{* *}$ \\
\hline
\end{tabular}

( Not: ** korelasyon katsayısı \% 99 güvenle anlamlı olduğunu göstermektedir.)
Korelasyon analizi sonuçlarına göre tüm boyutlar arasında pozitif yönlü anlamlı bir ilişki bulunmaktadır $(p<0,01)$. Boyutlar arasındaki ilişkiler belirlendikten sonra performans algısı boyutlarının stres faktörlerinden etkilenmesini gösteren doğrusal regresyon analizi yapılmıştır.

5.5.8.1. İ̧ Başarısının Stres Faktörlerinden Etkilenme Düzeyini Gösteren Doğrusal Regresyon Analizi Sonuçları

Performans algısının birinci boyutu olan İş başarısı, Bireyden, İş yapısından ve Genel çevresel unsurlardan kaynaklanan stres faktörlerinden anlamlı olarak etkilenmektedir $(p<0,01)$. Ancak Örgütsel yapı ve politikalardan kaynaklanan ile Örgüt içi fiziksel koşullardan kaynaklanan stres değişkenleri anlamsız bulunmuştur.

Anlamsız değişkenler çıkarıldıktan sonra oluşturulan regresyon modeline göre; Bireyden kaynaklanan, İş yapısından kaynaklanan ve Genel çevresel unsurlardan kaynaklanan stres faktörlerindeki bir birim değişiklik performans faktörlerinden iş başarısında artışa neden olmaktadır. Bireyden kaynaklanan stres

Tablo 9: Regresyon Analizinin Son Modeli (Anlamsız Değişkenler Çıkarıldıktan Sonra)

\begin{tabular}{|c|c|c|c|c|c|c|c|}
\hline \multicolumn{2}{|r|}{ Model } & Katsayı & $\mathrm{t}$ & $\mathrm{P}$ & $\mathrm{F}$ & $\mathrm{p}$ & $\mathrm{R}^{2}$ \\
\hline \multirow{4}{*}{ İş Başarısı } & Model Sabiti & 1,707 & 8,874 & 0,000 & \multirow{4}{*}{64,83} & \multirow{4}{*}{0,000} & \multirow{4}{*}{0,361} \\
\hline & Birey & 0,238 & 4,873 & $0,000^{* *}$ & & & \\
\hline & İş yapısı & 0,282 & 4,357 & $0,000^{* *}$ & & & \\
\hline & Genel çevresel unsurlar & 0,165 & 4,637 & $0,000^{* *}$ & & & \\
\hline
\end{tabular}

( Not: ${ }^{* *} 0,01$ 'e göre anlamlı olduğunu göstermektedir.)

faktörlerindeki bir birimlik değişiklik iş başarısında 0,238 değerinde, İş yapısından kaynaklanan stres faktörlerindeki bir birimlik değişiklik iş başarısında 0,282 değerinde ve Genel çevresel unsurlardan kaynaklanan stres faktörlerindeki bir birimlik değişiklik iş başarısında 0,165 değerinde artışa neden olmaktadır. Regresyon modeli aşağıdaki şekilde formüle edilmiştir.

İş Başarısı $=1,707+0,238$ (Birey) + 0,282 (İş Yapısı) $+0,165$ (Genel Çevresel Unsurlar)

Bireyden, İş yapısından ve Genel çevresel unsurlardan kaynaklanan stres, iş başarısı performansının $\% 36,1^{\prime}$ ini açıklamaktadır. İs başarısının geriye kalan yüzdesini ise başka nedenler belirlemektedir.
5.5.8.2. İ̧ Doyumunun Stres Faktörlerinden Etkilenme Düzeyini Gösteren Doğrusal Regresyon Analizi Sonuçları

Regresyon analizi performans algısının diğer boyutu olan İş doyumu için gerçekleştirildiğinde İş yapısından ve Örgüt içi fiziksel koşullardan kaynaklanan stres boyutlarının anlamsız oldukları görülmüştür $(p>0,01)$. 
Tablo 10: Regresyon Analizinin Son Modeli (Anlamsız Değişkenler Çıkarıldıktan Sonra)

\begin{tabular}{|c|c|c|c|c|c|c|c|}
\hline \multicolumn{2}{|r|}{ Model } & Katsayı & $\mathrm{t}$ & $\mathrm{p}$ & $\mathrm{F}$ & $\mathrm{p}$ & $\mathrm{R}^{2}$ \\
\hline \multirow{4}{*}{ İş Doyumu } & Model Sabiti & 2,057 & 14,418 & 0,000 & \multirow{4}{*}{91,19} & \multirow{4}{*}{0,000} & \multirow{4}{*}{0,444} \\
\hline & Birey & 0,318 & 6,295 & $0,000^{* *}$ & & & \\
\hline & Örgütsel yapı ve politikalar & 0,161 & 3,070 & $0,000^{* *}$ & & & \\
\hline & Genel çevresel unsurlar & 0,155 & 4,381 & $0,000^{* *}$ & & & \\
\hline
\end{tabular}

( Not: ** 0,01'e göre anlamlı olduğunu göstermektedir.)

Anlamsız iki değişken çıkarılarak analiz tekrarlandığında elde edilen sonuçlara göre oluşturulan regresyon modeline göre; Bireyden kaynaklanan, Örgütsel yapı ve politikalardan kaynaklanan ve Genel çevresel unsurlardan kaynaklanan stres faktörlerindeki bir birim değişiklik iş doyumunda artışa neden olmaktadır. Bireyden kaynaklanan stres faktörlerindeki bir birimlik değişiklik iş doyumunda 0,318 değerinde, Örgütsel yapı ve politikalardan kaynaklanan stres faktörlerindeki bir birimlik değişiklik iş doyumunda 0,161 değerinde ve Genel çevresel unsurlardan kaynaklanan stres faktörlerindeki bir birimlik değişiklik iş doyumunda 0,155 değerinde artışa neden olmaktadır. Regresyon modeli aşağıdaki şekilde formüle edilmiştir.

İs Doyumu $=2,057+0,318$ (Birey) $+0,161$ (Örgütsel Yapı ve Politikalar) + 0,155 (Genel Çevresel Unsurlar)

Bireyden, Örgütsel yapı ve politikalardan ve Genel çevresel unsurlardan kaynaklanan stres, iş doyumu performansının \% 44,4'ünü açıklamaktadır. İş doyumunun geriye kalan oranını ise başka nedenler belirlemektedir.

Performansın her iki alt boyutunda da artış görülmektedir. Anlamlı olarak bulunan stresin alt faktörlerindeki artış, çalışanların performanslarında artışa neden olmaktadır.

\section{SONUÇ VE ÖNERILER}

Stres son yıllarda örgütlerin önem verdiği ve çalışanları için önlem almaya çalıştığı bir sorundur. Stres bir tepki durumudur. Beklenmeyen bir durumun, baskı veya zorlamanın yol açtığı stres, çalışanlarda motivasyon kaybı, dikkatsizlik, iş kazaları, verimsizlik, işe devamsızlık, işe gitmede isteksizlik, performans düşüklüğü gibi sonuçlar doğurmaktadır. Örgütler bu sorunları yok etmek için strese neden olan unsurları yok etmeli veya düzeltmeli, stresin verebileceği olumsuz etkileri en aza indirmelidir.

Örgütsel strese neden faktörler ve öğretim elemanlarının örgütsel stres düzeyleri ile bunun iş performanslarına etkisinin tespit edilmesini amaçlayan bu çalışmada Trakya bölgesinde bulunan üniversite- lerde görev yapmakta olan 340 öğretim elemanına anket uygulanmıştır. Araştırma sonucu elde edilen bulgular incelendiğinde, öğretim elemanlarında en çok stres yaratan faktörlerin başında "iş yoğunluğu", ardından "yetersiz maaş ve ücret dengesizliği", "aileye ve sosyal yaşama vakit ayıramama" ve "işi belli sürede bitirme zorunluluğu" gelmektedir.

Bilimsel araştırma, inceleme yapma, kitap, makale yazma gibi etkinlikler öğretim elemanlığının özel yaşama yer veremeyecek denli sorumluluk, çaba ve sevgi gerektiren bir uğraş olduğunu göstermektedir. Ancak yoğun ders yükü altında bunalan, son bilimsel gelişmeleri izleyemeyen, akademik unvan elde etmede, yükseltilmede, kadrolara atanmada subjektif ilkelere maruz kalan akademisyenlik cazibesini yitirmektedir. Öğretim elemanlarının içinde yer aldığı üniversite ortamının olumsuz fiziki koşulları, kalabalık sınıflar, araç gereç, materyal yokluğu gibi sorunlar, mesleğin gerektirdiği bilimsel bilgiye ulaşmayı, araştırma ve uygulama yapmayı engellemektedir. Ayrıca maddi olanaksızlıklardan oluşan aşıı ders yükü öğretim elemanlarının araştırma çalışmalarını engellemektedir. Öğretim elemanlarının aldıkları maaş ve ders ücretlerinin yetersizliği, başarılı mezunların bu mesleğe ilgi göstermemesine yol açmakta, genç bilim adamları için üniversitede kariyer yapmak önem ve cazibesini yitirmektedir (Aytaç, vd. 2001: 65-67). Yetersiz maaş ve ücret dengesizliğini gidermek amacıyla ek ders ve gece öğretimi derslerinin verilmesi, ders saatlerinin fazla olmasına neden olmakta ve bu da öğretim elemanının iş yoğunluğunu arttırmaktadır. İş yoğunluğundaki artış da aileye ve sosyal yaşama vakit ayıramamaya neden olmaktadır.

Bireyden kaynaklanan stres faktörlerinden etkilenme düzeylerinde mesleki tecrübe süresi açısından 21 yıl ve üzeri sürede çalışanların stres düzeyleri daha yüksektir. Kurumda çalışılan süre açısından ise 1-5 yıl arası çalışanlar bireyden kaynaklanan stres faktörlerinden daha fazla etkilenmektedir. Buna bireyin kuruma ve işe uyum sağlama süreci neden olabilmektedir.

İs yapısından kaynaklanan stres faktörlerinden etkilenme düzeyleri unvan açısından değerlendirildiğinde en fazla etkilenen çalışanların uzmanlar olduğu 
görülmektedir. Bunun nedeni olarak çalışma saatlerindeki belirsizlik, araç gereç eksikliği, işte hata yapma olasılığı sayılabilmektedir. Mesleki tecrübe süresine bakıldığında iş yapısından kaynaklı stresten 1-10 yıl arası çalışanlar daha fazla etkilenmektedir. Kurumda çalışılan süre açısından ise 1-5 yıl arası çalışanlar iş yapısından kaynaklanan stresten daha fazla etkilenmektedirler. Yine bunun sebebi olarak akademik kariyere yeni başlayan öğretim elemanlarında çalışma yaşamının yarattığı sorunlar, aşırı ders yükü, monotonluk, mesleki riskler, işin göz önünde yapılması sayılabilmektedir.

Örgütsel yapı ve politikalardan kaynaklanan stres faktörlerinden etkilenme düzeyleri, mesleki tecrübe bakımından 21 yıl ve üzeri çalışanlarda daha yüksektir. Kurumda çalışılan süre boyutu incelendiğinde 1-5 yıl arası çalışanlar ile 11 yıl ve üzeri çalışanların örgütsel yapı ve politikaları daha fazla stres etkeni olarak gördüğü görülmektedir. Kurumun kendi yapısının ve işleyişinin neden olduğu unsurlar strese neden olmaktadır.

Performans algısında ise kadınların iş başarısının erkeklere göre daha yüksek olduğu ve 56 yaş ve üzeri çalışanların iş doyumlarının daha yüksek olduğu saptanmıştır. 56 yaş ve üzeri öğretim elemanlarında kariyer sonu denilen aşamaya gelinmesi, sadece tecrübelerinden yararlanarak kazandıkları bilgiyi öğretmeye çalışmaları ve emeklilik planları yapmaya başlamaları, iş doyumlarını arttıran unsurlar olarak sayılabilmektedir.

Öğretim elemanlarında görülen stres orta düzeylerde olup performanslarını arttırdığı görülmektedir. Olumlu veya yapıcı stres olarak adlandırılan bu durumda orta düzeydeki stres seviyeleri performansı arttıııı özellik taşımaktadır. Üniversitelerde öğretim elamanlarının stres düzeylerini aşağı çekebilmek için yöneticilerin bu doğrultuda yapabilecekleri:

- Öğretim elemanları arasındaki yükselme hırsı ve rekabete bağlı olarak ortaya çıkan sorunları azaltmak,

- Öğretim elemanlarının iş arkadaşları ile uyumsuzluk ve çatışma yaşamasını önlemek,

- Öğretim elemanlarının işin yoğunluğunu düzeltmek,

- Öğretim elemanlarına yeterli araç ve gereçleri temin etmek,

- Öğretim elemanlarının çalışma saatlerindeki belirsizlik veya uygunsuzluğu gidermek,

- Örgütsel amaç ve politikalara uymaya çalışmak,

- Görev dağılımındaki adaletsizliği önlemek,

- Öğretim elemanlarına kendi ürettiği işin dışında da bilgi vermek,

- Ücret dengesizliğini çözümlemek,

- Öğretim elemanları mesleki yönden kendilerini geliştirme olanaklarını sağlamak,

- Öğretim elemanlarını takdir etmek,

- Öğretim elemanlarına karar aşamasında destek vermek,

- Öğretim elemanları kararlara katılabilmek,

- Öğretim elemanlarının yönetsel uygulamaları eleştirebilmesine imkan vermek,

- Performans değerlendirmedeki adaletsizliği gidermek,

- Gizli ayrımcılık ve adam kayırmanın önüne geçmek, şeklinde sıralanabilir.

Bu sayede öğretim elemanlarında stres yaratan bu faktörlerin performanslarını azaltıcı etkisi önlenebilecek veya azaltılabilecektir. 


\section{KAYNAKLAR}

Akgemci, T. ve Güleş, H.K. (2010) İşletmelerde Stratejik Yönetim, 2. Baskı, Ankara, Gazi Kitabevi.

Aksoy, A. ve Kutluca, F. (2004) "Çalışma Hayatında Stres Kaynakları, Stres Belirtileri ve Stres Sonuçlarının İncelenmesi Üzerine Bir Araştırma" Sosyal Siyaset Konferanslar Dergisi, 49: 457-486.

Arrington, P. (2008) Stress At Work: How Do Social Workers Cope?, Washington, National Association Of Social Workers.

Aydın, A., Üçüncü, K. ve Taşdemir, T. (2011) "Akademik Performansı Etkileyen Stres Kaynaklarının Belirlenmesine Yönelik Bir Alan Çalışması” Uluslararası İnsan Bilimleri Dergisi, 8(2): 387-399.

Aydın, Ş. (2004) "Otel İşletmelerinde Stres Faktörleri İle İş Bırakma İlişkisi: 4-5 Yıldızlı Otel İşletmeleri Uygulaması" Yayınlanmamış Doktora Tezi, İzmir, Dokuz Eylül Üniversitesi Sosyal Bilimler Enstitüsü.

Aytaç, M., Aytaç, S., Fırat, Z., Bayram, N. ve Keser, A. (2001) Akademisyenlerin Çalı̧̧ma Yaşamı ve Kariyer Sorunlar, Bursa, Uludağ Üniversitesi Araștırma Fonu İsletmesi.

Aytaç, S. (1997) Çalışma Yaşamında Kariyer Yönetimi, Planlaması, Geliştirilmesi, Sorunlar, İstanbul, Epsilon Yayıncllı.

Aytaç, S. (2005) "Çalışanların İşlerine İlişkin Duygularının Stres Tepkileri Üzerindeki Etkisi” İstanbul Üniversitesi İktisat Fakültesi Dergisi, 55(1): 833-851.

Balcı, A. (1993) "Üniversite Öğretim Elemanının İş Stresi Ölçeği” Ankara Üniversitesi Eğitim Bilimleri Fakültesi Dergisi, 26(1): 315-334.

Blaug, R., Kenyon, A. ve Lekhi, R. (2007) Stress At Work, London, The Work Foundation.

Cicei, C.C. (2012) "Occupational Stress And Organizational Commitment In Romanian Public Organizations" Social and Behavioral Sciences, 33: 1077-1081.

Daft, R.L. (1991) Management, Second Edition, Orlando, The Dryden Press.

Ergun, G. (2008) "Sağglık İşletmelerinde Örgütsel Stresin İşgücü Performansıyla Etkileşiminin İncelenmesi” Yayınlanmamış Yüksek Lisans Tezi, İzmir, Dokuz Eylül Üniversitesi Sosyal Bilimler Enstitüsü.

George, J.M. ve Jones, G.R. (2012) Understanding and Managing Organizational Behavior, Sixth Edition, New Jersey, Pearson Education Inc.

Greiner, A. (2008) "An Economic Model Of Work-Related Stres" Journal of Economic Behavior \& Organization, 66: 335-346.

Gümüştekin, G.E. ve Öztemiz, A.B. (2005) "Örgütlerde Stresin Verimlilik ve Performansla Etkileşimi" Çukurova Üniversitesi Sosyal Bilimler Enstitüsü Dergisi, 14(1): 271-288.
Kara, D. ve Koç, H. (2009) “Öğretim Elemanlarının Stresle Başa Çıkma Davranışlarının Bazı Değiş̧kenlere Göre Belirlenmesi” İ̧sletme Araştırmaları Dergisi, 1(2): 35-50.

Kast, F.E. ve Rosenzweig, J.E. (1985) Organization and Management, First Edition, Singapore, Mcgraw-Hill Book.

Kavanagh, J. (2005) Stress and Performance, USA, the Rand Corporation.

Koç, H. ve Topaloğlu, M. (2012) İşletmeciler İ̧̧in Yönetim Bilimi, 2. Baskı, Ankara, Seçkin Yayıncılık.

Leontaridi, R.M. ve Ward, M.E. (2002) Work-Related Stress, Quitting Intentions and Absenteeism, Germany, IZA Discussion.

Lorcu, F. ve Bilgen, E. (2009) "Stresin Çalışanların Performansı Üzerindeki Etkisine Yönelik Bir Araştırma” 2. Ulusal Yönetim ve Ekonomi Bilimleri Konferansı Bildiriler Kitabı, 3: 241-256.

Okutan, M. ve Tengilimoğlu, D. (2002) "İş Ortamında Stres ve Stresle Başa Çıkma Yöntemleri: Bir Alan Uygulaması" Gazi Üniversitesi İktisadi ve İdari Bilimler Fakültesi Dergisi, 3:1-33.

Özer, M.A. (2011) 21. Yüzyılda Yönetim ve Yöneticiler, 2. Baskı, Ankara, Nobel Yayıncılık.

Park, J. (2007) "Work Stress and Job Performance" Perspectives Statistics, Canada, December: 5-17.

Salami, A.O., Ojokuku, R.M. ve Ilesanmi, O.A. (2010) "Impact Of Job Stress On Managers' Performance" European Journal Of Scientific Research, 45(2): 249-260.

Schermerhorn, J.R. (1996) Management, Fifth Edition, USA, John Wiley \& Sons Inc.

Sonnentag, S., Volmer, J. ve Spychala, A. (2008) "Job Performance" Handbook of Organizational Behavior, 1: 427-447.

Sonnentag, S. (2002) Psychological Management of Individual Performance. UK, John Wiley \& Sons Ltd.

Thong, J.Y.L. ve Yap, C. (2000) "Information Systems And Occupational Stress: A Theoretical Framework" Omega The International Journal Of Management Science, 28: 681-692.

Tuten, T.L. ve Neidermeyer, P.E. (2004) "Performance, Satisfaction And Turnover In Call Centers, The Effects of Stress and Optimism" Journal of Business Research, 57: 26-34.

Yılmaz, A. ve Ekici, S. (2003) "Örgütsel Yaşamda Stresin Kamu Çalışanlarının Performansına Etkileri Üzerine Bir Araştırma” Yönetim ve Ekonomi Dergisi, 10(2): 1-19. 